\title{
DEKOMPOZYCJA MIECDZYNARODOWEJ POZYCJI INWESTYCYJNEJ POLSKI NA TLE WYBRANYCH KRAJÓW EUROPY ŚRODKOWO-WSCHODNIEJ
}

\begin{abstract}
Streszczenie. Na przełomie XX i XXI w. na świecie zaszły znaczące zmiany w strukturze zewnętrznej pozycji inwestycyjnej krajów. W państwach Azji i Środkowego Wschodu zanotowano dynamiczny wzrost nadwyżek finansowych, natomiast w pozostałych krajach rozwijających się zauważono znaczący wzrost kapitału udziałowego w pasywach ogółem oraz silną akumulację rezerw walutowych. Generalnie, w dobie postępującej globalizacji finansowej od lat 70. i 80. XX w. następuje dynamiczny wzrost udziału pasywów MPI w PKB krajów rozwiniętych. Od lat 90. XX w. do początku XXI w. zauważyć można wysokie tempo wzrostu kapitału udziałowego w strukturze kapitału. Celem opracowania jest analiza międzynarodowej pozycji inwestycyjnej Polski na tle wybranych krajów Europy Środkowo-Wschodniej oraz krajów strefy euro.
\end{abstract}

Słowa kluczowe: międzynarodowa pozycja inwestycyjna, bezpośrednie inwestycje zagraniczne, integracja finansowa, struktura MPI.

\section{WPROWADZENIE}

Międzynarodowa pozycja inwestycyjna jest zestawieniem, które przedstawia stany zagranicznych aktywów i pasywów rezydentów wobec nierezydentów na koniec danego okresu. Różnica pomiędzy wielkością aktywów i pasywów zagranicznych stanowi międzynarodową pozycję inwestycyjną netto i informuje, czy kraj jest wierzycielem czy też dłużnikiem netto w stosunku do zagranicy.

Od lat 70. i 80. XX w. następuje dynamiczny wzrost udziału pasywów w PKB krajów rozwiniętych (Total Liabilities/GDP). W okresie od początku lat 90. XX w. do początku XXI w. nastąpił bardzo dynamiczny wzrost udziału kapitału o charakterze własnościowym w PKB $(E Q I=(F D I+$ Portfolio Equity $) / G D P)$. Od lat 70. do 2004 r. wskaźnik EQI wzrósł o ok. 40 p.p. (z poziomu ok. 5\% PKB do ok. $45 \%$ PKB) w krajach rozwiniętych, natomiast w krajach rozwijających się wzrost był ok. 20 p.p. (z poziomu ok. 10\% PKB do ok. 30\% PKB). Interesujący jest fakt, że od lat 70 . XX w. do ok. połowy lat 80 . w badanej grupie gospodarek rozwijają-

* Uniwersytet Łódzki, Wydział Ekonomiczno-Socjologiczny, Katedra Międzynarodowych Stosunków Gospodarczych. 
cych się udział kapitału udziałowego w strukturze kapitału ogółem (Equity Share/ Total Liabilities) obniżył się (o ok. 50\%) z poziomu około $35 \%$ do poziomu średnio ok. 16-18\%. W krajach bogatych spadek ten był nieco łagodniejszy (około 10 p.p.) i osiągnął poziom ok. $25 \%$ pasywów. Od lat 90 . w obu grupach krajów zauważyć można wysokie tempo wzrostu kapitału udziałowego w strukturze kapitału. W krajach bogatych wzrost kapitału udziałowego w pasywach osiągnął w 2000 r. średnio ok. $40 \%$, natomiast po tym okresie jego odsetek obniżył się do ok. $30 \%$, w przeciwieństwie do pozostałych krajów, w których nastąpił wzrost jego udziału do ok. $50 \%$ w pasywach ogółem.

Celem opracowania jest analiza statystyczna wybranych danych dotyczących międzynarodowej pozycji inwestycyjnej Polski na tle wybranych krajów Europy Środkowo-Wschodniej oraz krajów strefy euro. Ponadto w opracowaniu podjęto próbę odpowiedzi na pytanie, czy klimat inwestycyjny w danej gospodarce może mieć odzwierciedlenie w strukturze zewnętrznej międzynarodowej pozycji inwestycyjnej, szczególnie pasywach, a w nich w relacji pomiędzy kapitałem udziałowym i dłużnym. Interesujące jest także, czy wzrost kapitału własnego może być skorelowany z lepszym podziałem międzynarodowego ryzyka i większą stabilnością finansową.

\section{WYBRANE ASPEKTY TEORETYCZNE}

P. R. Lane oraz G. M. Milesi-Ferretti (2000) dokonują przeglądu literatury przedmiotu odnoszącej się do istoty oraz struktury zewnętrznej pozycji inwestycyjnej krajów. Na tej podstawie dokonują wyboru potencjalnych determinant określających strukturę finansową bilansów płatniczych krajów rozwiniętych i rozwijających się. Szczególna uwaga skupia się w obszarze badanych relacji struktury długu i kapitału udziałowego (BIZ plus kapitał portfelowy). Konstruują w tym celu modele, badają korelacje oraz zależności pomiędzy poszczególnymi zmiennymi. Wśród badanych krajów znalazły się 22 kraje zakwalifikowane przez autorów jako rozwinięte oraz 110 krajów rozwijających się i przechodzących transformację. Ponadto dokonano podziału wyżej wymienionych krajów na pięć stref geograficznych, wśród których wymienić można: Afrykę Subsaharyjską, Środkowy Wschód i Afrykę Północną, Azję, Amerykę Łacińską oraz gospodarki rozwijające się/transformujące się. Dodatkowo wyodrębniono grupę krajów tzw. uprzemysłowionych. Analiza otrzymanych wyników na podstawie funkcji regresji pozwoliła na sformułowanie interesujących wniosków. Jednym z nich jest ten, który stanowi, iż kraje relatywnie większe z rozwiniętym rynkiem finansowym oraz cechujące się dużą otwartością handlową charakteryzuje zdywersyfikowana zewnętrzna struktura finansowa (external diversification). Natomiast w grupie krajów rozwijających się dominuje zróżnicowana struktura pasywów. Zarówno kraje rozwinięte, jak i rozwijające się, zaliczane do grupy o wysokim PKB na 
mieszkańca, posiadają wyższe poziomy aktywów, a także pasywów, a ponadto zwykle są większymi kredytodawcami niż kraje mniejsze. Zdaniem autorów (Lane, Milesi-Ferretti 2000) otwartość handlowa krajów sprzyja przepływom kapitału we wszystkich formach, jednak w nieco większym stopniu przeważa przepływ kapitału udziałowego, w szczególności bezpośrednich inwestycji zagranicznych, wobec długu. Podsumowując, można stwierdzić, że wielkość kraju, poziom rozwoju gospodarki oraz stopień rozwoju rynku kapitałowego sprzyjają napływowi kapitału udziałowego.

Inni badacze (Faria, Lane, Mauro, Milessi-Ferretti 2006), w wyniku przeprowadzonej analizy przekrojowo-czasowej gospodarek, dokonują wyboru czynników określających strukturę pasywów międzynarodowej pozycji inwestycyjnej krajów w podziale na państwa o wysokim dochodzie i państwa pozostałe. Autorzy wyodrębnili dwa okresy tj. 1996 r. oraz 2004 r. Wśród badanych zmiennych wybrano do analiz współczynnik będący ilorazem pasywów zagranicznych w relacji do PKB oraz wskaźnik określający udział kapitału własnego w pasywach ogółem, a także iloraz bezpośrednich inwestycji zagranicznych i kapitału udziałowego w PKB. Wyniki obliczeń dla dwóch badanych okresów są bardzo zbliżone, co pozwala na wysunięcie wspólnych wniosków. Od lat 70. do połowy lat 80. XX w. w badanych krajach udział pasywów ogółem w PKB był na bardzo zbliżonym poziomie, tj. od ok. $25-30 \%$ do ok. 50\% PKB. Od ok. połowy lat 80 . nastąpiło rozwarcie trajektorii reprezentujących posiadane pasywa przez kraje bogate i pozostałe. Kraje bogate charakteryzują się dużo wyższym poziomem udziału pasywów w PKB (w 2004 r. osiągnęły poziom ponad 140\% udział pasywów w PKB), w porównaniu z pozostałymi krajami, dla których badany współczynnik osiągnął wielkość ok. $60 \%$ PKB w tym samym okresie. Ponadto wzrost udziału kapitału własnego w pasywach ogółem rachunku finansowego bilansu płatniczego jest dodatnio skorelowany z jakością zmian instytucjonalnych w badanych krajach. Zauważono też, iż większe kraje charakteryzuje relatywnie mniejszy udział pasywów zagranicznych, natomiast większy udział kapitału portfelowego w pasywach ogółem. Dla 2004 r. analiza przekrojowa ujawniła dodatnią korelację pomiędzy udziałem kapitału własnego a większą otwartością handlową gospodarek.

Lane i Milesi-Ferretti (2006), na podstawie danych pochodzących ze $145 \mathrm{kra}-$ jów w okresie 1970-2004, dokonują syntetycznej analizy danych oraz uzyskanych wyników obliczeń. Przedmiotem badań jest międzynarodowa pozycja inwestycyjna badanych krajów. Uwaga koncentruje się na strukturze aktywów i pasywów MPI oraz na próbie wyłonienia na tej podstawie tendencji w zewnętrznej strukturze finansowej badanych krajów. Do tego celu autorzy wykorzystali wskaźniki służące do oceny stopnia międzynarodowej integracji finansowej. Jednym z nich jest iloraz sumy zewnętrznych aktywów oraz pasywów w relacji do PKB. Generalnie można stwierdzić, że otrzymane wyniki dla krajów rozwiniętych i rozwijających się są zbliżone. Nastąpił siedmiokrotny wzrost współczynnika określającego stopień międzynarodowej integracji finansowej z poziomu ok. 45\% PKB 
w 1970 r. do poziomu ponad 300\% PKB w 2004 r. Na tej podstawie wyróżniono dwa etapy postępującej globalizacji finansowej. Pierwszy odnosi się od lat 70 . do lat 80., w którym wzrost integracji wynosił średniorocznie kilkadziesiąt procent PKB, by w 1987 r. osiągnąć ok. 100\% PKB. Wyraźne przyspieszenie procesu międzynarodowej integracji finansowej miało miejsce w latach 90., kiedy to wskaźnik osiągnął poziom 200\% PKB w 1998 r. i 300\% PKB w 2004 r. Różnice pomiędzy obiema grupami krajów są widoczne, gdy do analizy porównawczej dołączony zostanie wskaźnik odnoszący się do stopnia międzynarodowej integracji handlowej (udział sumy aktywów i pasywów finansowych w relacji do sumy eksportu i importu). W 2004 r. rozbieżność pomiędzy dwiema badanymi grupami krajów stanowiła ok. 500\% (kraje rozwinięte - ok. 700\% i kraje rozwijające się ok. 200\%). Dla krajów rozwiniętych wyróżnić można trzy fazy ewolucji stopnia międzynarodowej integracji finansowej. Pierwsza, trwająca do 1985 r., kiedy poziom wskaźnika zachowywał się w miarę stabilnie. W latach 1985-1995 jego wielkość ulegała systematycznemu wzrostowi. Natomiast od 1996 r. zmiany były znaczące, za wyjątkiem lat 2001-2002, w których nastąpił spadek w przepływie kapitału udziałowego. W krajach rozwijających się lata 90. można nazwać okresem silnej integracji w obszarze kapitału udziałowego zarówno w relacji do PKB, jak i w stosunku do wymiany handlowej. Na podstawie otrzymanych wyników zauważono dodatkowo, że na przełomie milenium zaszły znaczące zmiany w zewnętrznej pozycji inwestycyjnej badanych krajów. W krajach rozwiniętych dostrzeżono znaczący wzrost zarówno po stronie aktywów, jak i pasywów w relacji do PKB, szczególnie gdy chodzi o dłużników netto (np. Stany Zjednoczone, Australia, Hiszpania) oraz wierzycieli (Japonia, Szwajcaria). W grupie krajów rozwijających się z Azji i Środkowego Wschodu zewnętrzna pozycja inwestycyjna od lat 90. do 2004 r. uległa poprawie. Podsumowując, w dobie postępującej globalizacji finansowej zauważono znaczące zmiany w strukturze bilansów płatniczych i międzynarodowej pozycji inwestycyjnej badanych krajów. Kraje Azji i Środkowego Wschodu zanotowały dynamiczny wzrost nadwyżek finansowych. W pozostałych państwach rozwijających się zauważono znaczący wzrost kapitału udziałowego w pasywach ogółem oraz silną akumulację rezerw walutowych.

\section{TENDENCJE W ZEWNECTRZNEJ STRUKTURZE KAPITALU}

Na przełomie XX i XXI w. zaszły znaczące zmiany w zewnętrznej pozycji inwestycyjnej w gospodarce światowej. W krajach rozwijających się Azji i Środkowego Wschodu nastąpiła poprawa zewnętrznej pozycji inwestycyjnej, natomiast w europejskich krajach rozwijających się dokonały się zmiany w strukturze kapitału. W państwach uznanych za rozwinięte ich zewnętrzna pozycja inwestycyjna wobec PKB wzrosła za sprawą relatywnie wyższego udziału zobowiązań w strukturze MPI (Australia, Hiszpania, Stany Zjednoczone) oraz relatywnie 
większego udziału aktywów w strukturze MPI (Japonia, Szwajcaria). W odniesieniu do integracji finansowej krajów rozwijających się można stwierdzić, że skala tej integracji nie jest taka, jak w krajach rozwiniętych. To dotyczy w szczególności niskiego poziomu integracji finansowej w obszarze długu. Dalsza liberalizacja przepływów kapitałowych w tych krajach oraz dalszy progres w rozwoju finansowym narodowych rynków finansowych mogą mieć wpływ na postęp w dalszej międzynarodowej integracji finansowej.

Lane, Milesi-Ferretti (2006) dokonali analizy statystycznej zewnętrznej struktury kapitału w pasywach MPI krajów rozwiniętych i rozwijających się. W opracowaniu zbadano i porównano relację kapitału udziałowego (FDI + Portfolio Equity/TL) w pasywach ogółem. W latach 80. i 90. w obu grupach krajów nastąpił wyraźny wzrost kapitału udziałowego w pasywach ogółem. W latach 2000-2002 nastąpił spadek jego udziału na korzyść długu. W 2004 r. w krajach rozwiniętych kapitał udziałowy osiągnął poziom 36\% pasywów ogółem. W krajach rozwijających jego udział osiągnął poziom ok. 50\% pasywów ogółem, z tego ok. $75 \%$ stanowiły bezpośrednie inwestycje zagraniczne. Ponadto w gospodarkach rozwijających się zauważono jednocześnie dynamiczny wzrost akumulacji oficjalnych rezerw. Współczynnik określający udział oficjalnych rezerw w zobowiązaniach (długu) ogółem wzrósł z poziomu 29\% w 1998 r. do 64\% w 2004 r. Zmiany w strukturze zewnętrznej pozycji inwestycyjnej krajów wpłynęły np. na polepszenie pozycji inwestycyjnej krajów rozwijających się za sprawą m.in. wzrostu kapitału udziałowego oraz rezerw walutowych w pasywach ogółem. Na podstawie badań przekrojowo-czasowych na próbie składającej się z 67 krajów w okresie 1970-1998 Lane, Milesi-Ferretti (2001) zauważyli, że największy wpływ na kierunek międzynarodowego handlu aktywami mają produkt krajowy brutto per capita, dług publiczny oraz zmienne demograficzne. Natomiast ceny tychże aktywów, będących w międzynarodowym obrocie, determinuje zagraniczna pozycja inwestycyjna netto, która z kolei wywiera istotny wpływ na zachowanie się długoterminowego realnego kursu walutowego.

B. Gruić (2013) podjął próbę określenia determinant międzynarodowej pozycji inwestycyjnej wybranych krajów w świetle postępującej globalizacji finansowej. Dane kwartalne obejmują okres od IV kw. 1997 r. do II kw. 2004 r. Badania dotyczą grupy krajów będących członkami UE, ale nienależących do strefy euro. Wśród nich znajdują się: Czechy, Węgry, Polska, Słowacja, Słowenia, Bułgaria, Chorwacja oraz Rumunia. W artykule dokonano dekompozycji międzynarodowej pozycji inwestycyjnej netto badanej grupy krajów. Od końca 1997 r. wskaźnik BIZ/PKB (Foreign Direct Investments/GDP) wybranych krajów obniżył się z poziomu $-0,51$ do $-1,26 \mathrm{w}$ lipcu 2004 r., podczas gdy relacja inwestycji portfelowych wobec PKB (Portfolio Investments/GDP) osiągnęła -0,38 w $1997 \mathrm{r}$. i -0,54 w 2004 r. Pozostałe inwestycje względem PKB (Other Investments/GDP) wyniosły $-0,49 \mathrm{w} 1997 \mathrm{r}$. i -0,62 w $2004 \mathrm{r}$. Zdaniem autora powyższe dane świadczą o pozytywnej ocenie sytuacji gospodarczej w krajach rozwijających się przez 
inwestorów z zagranicy. Na szczególną uwagę zasługuje utrzymująca się długookresowa perspektywa zwrotu z zainwestowanego kapitału, co znalazło wyraz w postaci lokowanych BIZ-ów. Ponadto dla badanych krajów dokonano analizy ich stopnia międzynarodowej integracji finansowej. Kraje z wyższym poziomem aktywów i pasywów brutto w stosunku do PKB odznaczają się wyższym poziomem integracji finansowej $(I F I=(A+L) / G D P)$. Równocześnie pokazano ewolucję IFI oraz EQI (Equity investments; $E Q I=(E Q A+E Q L) / G D P)) \mathrm{w}$ okresie 1997-2004. Wynikiem analizy danych jest wniosek, który stanowi, iż na poziomie kapitału portfelowego integracja finansowa EQI wzrosła ponad dwukrotnie z 0,6 do 1,36 , podczas gdy integracja finansowa mierzona IFI wzrosła z poziomu 3,22 do poziomu 4,90 . Na tym tle pokazano stopień integracji finansowej w relacji do integracji handlowej. Dla Rumunii, Bułgarii oraz Węgier wyniki analizy pokazały, że integracja handlowa nie jest warunkiem koniecznym do silniejszej integracji finansowej gospodarek. Dla pozostałych badanych krajów integracja handlowa odgrywa kluczową rolę w procesie postępującej integracji finansowej. Gruić (2013) podsumowując stwierdza, że poziom aktywów i pasywów zależy zarówno od czynników krajowych, jak i zagranicznych. Wśród nich można wymienić: otwartość handlową, wielkość kraju, stopień rozwoju rynku kapitałowego oraz stopień liberalizacji finansowej. Dodatkowo za wyższym stopniem integracji mierzonej kapitałem udziałowym $(E Q I)$ w badanym okresie przemawia fakt relatywnie dużego udziału przedsiębiorstw państwowych poddawanych sukcesywnie prywatyzacji, co skutecznie zachęcało inwestorów zagranicznych do lokowania kapitału udziałowego zarówno w postaci BIZ-ów, jak i kapitału portfelowego.

Catao, Milesi-Ferretti (2013) podjęli próbę wyłonienia determinant kryzysów zewnętrznych, zwracając szczególną uwagę na rolę pasywów zagranicznych oraz ich strukturę. Okres badania obejmuje lata 1970-2011, a przedmiotem badania jest 70 krajów, wśród których 41 należy do krajów rozwijających się. Autorzy, wykorzystując do badania model Shina (2012), zauważyli, że gwałtownie wzrasta ryzyko kryzysu w danej gospodarce gdy poziom pasywów zagranicznych netto przekracza 50\% PKB $(N F L / G D P)$ i oscyluje pomiędzy $50-60 \%$ PKB, a także gdy wielkość wskaźnika $N F L / G D P$ przekroczy poziom 20 p.p. powyżej historycznego średniego poziomu danego kraju. W wyniku przeprowadzonego badania zauważono, że wzrasta prawdopodobieństwo wystąpienia kryzysu finansowego, gdy zwiększa się relatywnie udział długu wobec kapitału udziałowego w pasywach zewnętrznych kraju. Taka sytuacja dotyczy szczególnie krajów, których udział długu netto w pasywach przekracza poziom ok. 35\% PKB. Ryzyko wystąpienia kryzysu jest niższe, gdy wzrasta udział netto BIZ w strukturze kapitału $(F D I / T L)$. To spostrzeżenie jest zgodne $\mathrm{z}$ wynikami badań przeprowadzonymi przez Hausmanna, Fernandez-Ariasa (2001) oraz Borenszteina, de Gregorio i Lee (1998), z których wynika, iż istnieje pozytywny wpływ rosnącego relatywnie udziału BIZ-ów w pasywach MPI danego kraju. Im jest on wyższy, tym dany kraj jest bardziej stabilny i jest oceniany przez potencjalnych inwestorów jako 
bezpieczniejszy dla lokowanego kapitału. W literaturze przedmiotu bywa nazywany good cholesterol. Podobnie rzecz się ma z rezerwami walutowymi. Jeżeli ich udział w aktywach zagranicznych jest relatywnie wysoki, wówczas znaczenie prewencyjne tych rezerw wobec ryzyka kryzysowego jest większe. Co do wpływu portfela składającego się z kapitałów udziałowych (Portfolio Equity) na ryzyko wybuchu kryzysu wyniki badań okazały się niejednoznaczne. Zmienną, której rola w predykcji wystąpienia kryzysu w większości badanych specyfikacji jest największa, to deficyt bilansu obrotów bieżących (Current Account), którego poziom oscyluje wokół 4\% PKB. Generalnie w wyniku dekompozycji zewnętrznej pozycji inwestycyjnej netto badanych krajów na kapitał udziałowy netto oraz dług netto, wynika, że zmienna długu netto pasywów jest najistotniejszą determinantą zewnętrznej pozycji inwestycyjnej netto, która wywiera istotny wpływ na ryzyko wystąpienia kryzysu.

\section{MIĘDZYNARODOWA POZYCJA INWESTYCYJNA POLSKI - ANALIZA STATYSTYCZNA}

Analiza międzynarodowej pozycji inwestycyjnej netto Polski oraz jej poszczególnych komponentów netto $\mathrm{w}$ relacji do PKB dostarcza interesujących spostrzeżeń. $Z$ roku na rok MPI netto Polski wobec PKB Polski pogłębia się. W 2003 r. saldo MPI wynosiło -41,7\% PKB, natomiast w 2013 r. osiągnęło poziom $-69,3 \%$ PKB. Oznacza to, że saldo zobowiązań finansowych Polski wobec zagranicy wynosi średniorocznie dla badanego okresu $-54,7 \%$. Z kolei pasywa ogółem przekroczyły poziom PKB w 2010 r., osiągając 104,5\% PKB, natomiast w 2013 r. pasywa stanowily 109,7\% PKB. Może to świadczyć o tym, że Polska jest oceniana jako kraj stabilny finansowo i gospodarczo oraz coraz bardziej atrakcyjny dla inwestorów zagranicznych, którzy lokują kapitał zarówno długoterminowy w postaci bezpośrednich inwestycji zagranicznych netto $(-36,9 \%$ PKB w 2013 r. wobec $-27,0 \%$ PKB w 2004 r.), jak i kapitał portfelowy netto (odpowiednio: $-29,1 \%$ PKB wobec $-16,1 \%$ PKB).

Na podstawie danych przedstawionych na rys. 1 można stwierdzić, że w Polsce w latach 2007-2010 saldo netto kapitału krótkoterminowego wykazywało wartości ujemne. Kapitał portfelowy napływał do Polski podczas ostatniego kryzysu gospodarczego finansowego. Oznacza to, że rynek finansowy w Polsce oceniany był przez inwestorów jako stabilny i relatywnie rentowny. W $2008 \mathrm{r}$. nastąpił gwałtowny odpływ z Polski kapitału portfelowego. W tym samym okresie wzrósł udział pozostałych inwestycji zagranicznych netto w PKB o 8,3 p.p. wobec 2007 r. Uzupełnieniem powyższych spostrzeżeń jest analiza zdekomponowanych pozycji pasywów MPI Polski zarówno pod kątem ich struktury, jak i dynamiki w okresie 2004-2013. Na rys. 2 przedstawiono strukturę pasywów brutto międzynarodowej pozycji inwestycyjnej netto. 


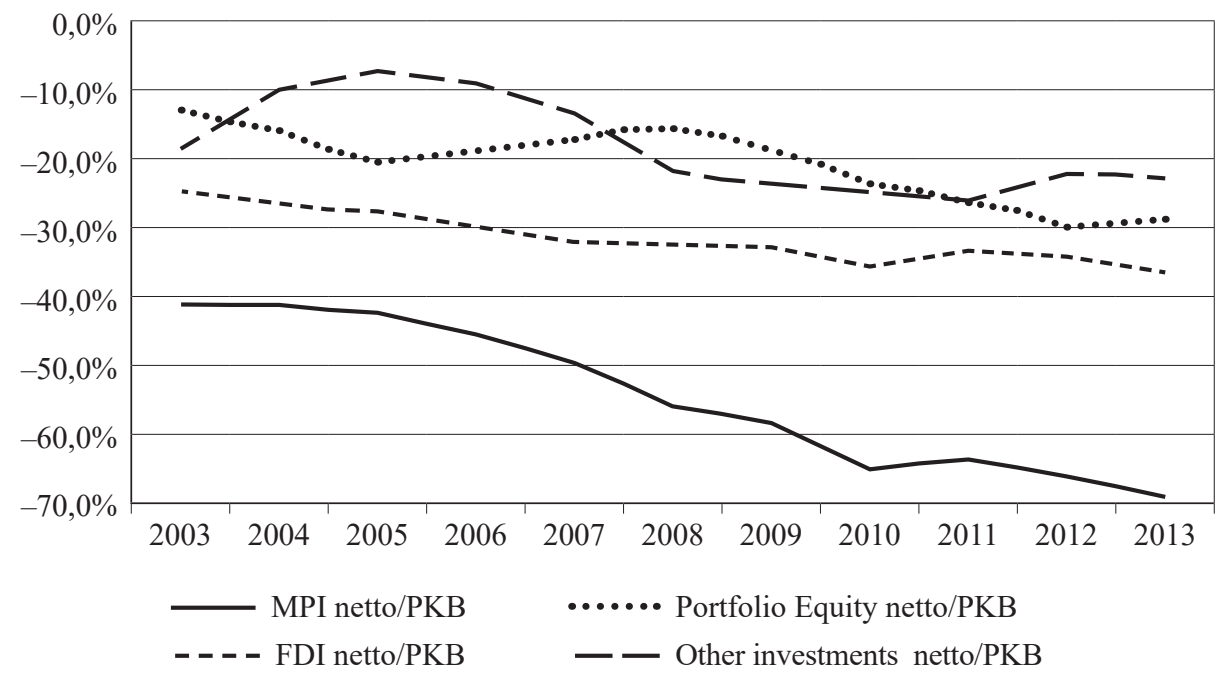

\begin{tabular}{|l|r|r|r|r|r|r|r|r|r|r|r|}
\cline { 2 - 11 } \multicolumn{1}{c|}{} & 2003 & 2004 & 2005 & 2006 & 2007 & 2008 & 2009 & 2010 & 2011 & 2012 & 2013 \\
\hline MPI netto/PKB [\%] & $-41,7$ & $-41,6$ & $-42,4$ & $-45,7$ & $-49,9$ & $-56,3$ & $-58,8$ & $-65,4$ & $-64,0$ & $-66,5$ & $-69,3$ \\
\hline FDI netto/PKB [\%] & $-24,7$ & $-27,0$ & $-28,0$ & $-30,6$ & $-32,5$ & $-32,6$ & $-33,0$ & $-35,8$ & $-33,6$ & $-34,5$ & $-36,9$ \\
\hline Portfolio Equity netto/PKB [\%] & $-13,4$ & $-16,1$ & $-20,8$ & $-19,5$ & $-17,2$ & $-15,6$ & $-18,7$ & $-23,7$ & $-25,8$ & $-30,4$ & $-29,1$ \\
\hline Other investments netto/PKB [\%] & $-18,7$ & $-10,3$ & $-7,7$ & $-8,9$ & $-13,8$ & $-22,1$ & $-23,9$ & $-25,1$ & $-26,2$ & $-22,6$ & $-22,8$ \\
\hline
\end{tabular}

Rys. 1. Elementy międzynarodowej pozycji inwestycyjnej netto Polski względem PKB w latach 2003-2013 (w \%)

Źródło: obliczenia własne na podstawie danych NBP.

W latach 2003-2013 w strukturze pasywów MPI Polski zauważyć można względnie stabilny udział poszczególnych jego składników w badanym okresie. Największy odsetek stanowiły BIZ-y lokowane w Polsce, których średnioroczny udział wynosił $42,3 \%$. Kolejną znaczącą pozycją finansową są inwestycje portfelowe (Portfolio Investmensts, PI), które stanowiły średnio ok. $26,7 \% \mathrm{w}$ badanym okresie. Od 2003 r. można zauważyć ich systematyczny wzrost, za wyjątkiem 2008 r. (20,5\%), kiedy nastąpiło gwałtowne ich wycofywanie z Polski, aby na koniec 2013 r. osiągnąć poziom 29,3\% w pasywach ogółem, tj. 525533 mln PLN. Na uwagę zasługuje analiza danych dotyczących kategorii finansowej, jaką są pozostałe inwestycje zagraniczne. Ich udział w pasywach MPI średniorocznie wynosił 30,3\% (najwyższy w 2003 r. 39,3\%; najniższy w 2006 r. 25,7\%). Pozostałe inwestycje zagraniczne (Other Investments, OI) obejmują udzielone kredyty handlowe, pożyczki finansowe, gotówkę na rachunkach bieżących oraz depozyty lokowane w Polsce, niezaliczane do pozostałych kategorii pasywów. Z chwilą przyjęcia Polski w poczet członków Unii Europejskiej udział OI był stosunkowo wysoki (ponad $30 \%$ ). Po tym okresie, jego odsetek obniżył się na korzyść inwestycji portfelowych 
oraz BIZ (Foreign Direct Investments, FDI). Na rys. 3 przedstawiono dynamikę pasywów MPI Polski. Można zauważyć, iż OI gwałtownie wzrosły do poziomu $35 \%$ w 2008 r., a w kolejnych latach wynosiły średnio ok. 29,5\%.

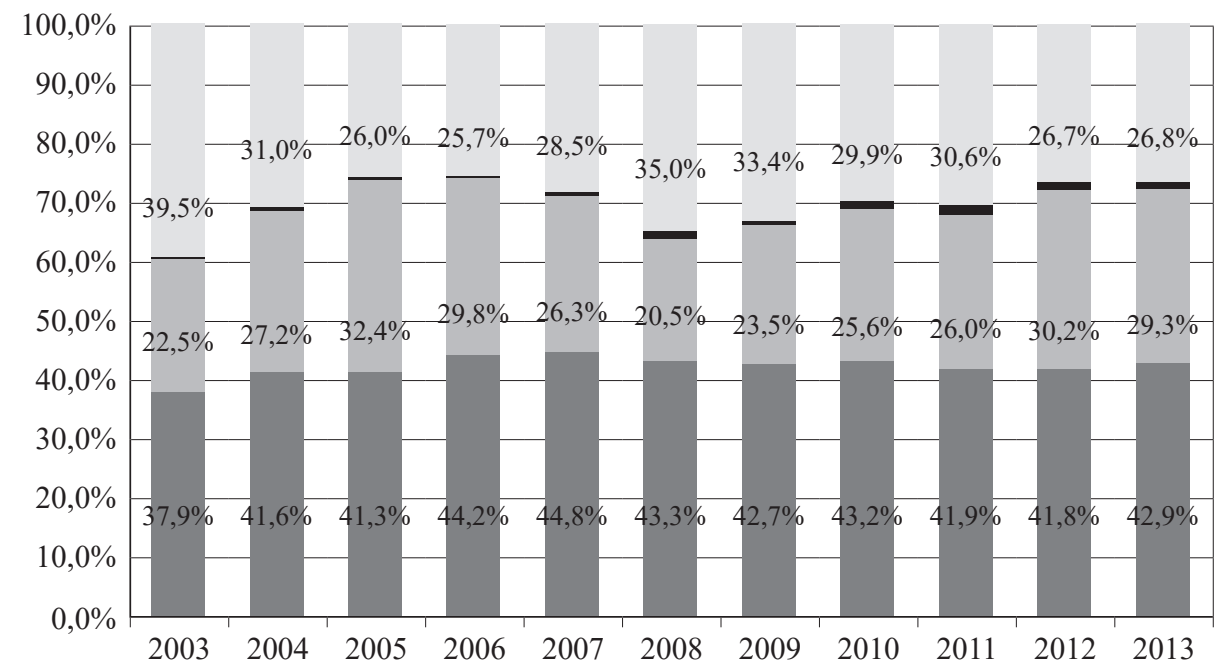

— Zagraniczne inwestycje bezpośrednie w Polsce $\square$ Zagraniczne inwestycje portfelowe w Polsce

- Pochodne instrumenty finansowe Pozostałe inwestycje zagraniczne

Rys. 2. Struktura pasywów MPI Polski w latach 2003-2013 (w \%)

Źródło: obliczenia własne na podstawie danych NBP i IMF.

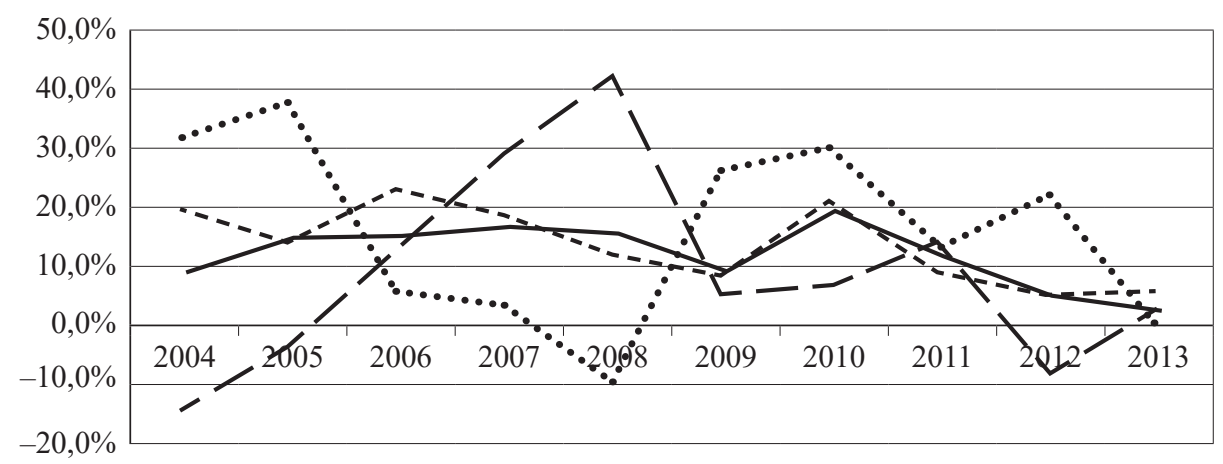

Pasywa ogółem

- - Pozostałe inwestycje zagraniczne
- - - - Zagraniczne inwestycje bezpośrednie w Polsce

...... Zagraniczne inwestycje portfelowe w Polsce

Rys. 3. Dynamika zmian pasywów Polski w latach 2004-2013 (rok poprzedni $=100)$

Źródło: obliczenia własne na podstawie danych NBP i IMF. 
W pasywach MPI Polski za lata 2003-2013, zgodnie z wcześniejszymi spostrzeżeniami, największe zmiany w czasie wykazywały inwestycje portfelowe oraz pozostałe inwestycje zagraniczne. Udział pochodnych instrumentów finansowych został w analizie pominięty ze względu na fakt, iż ich odsetek wynosił średnio w badanych latach w aktywach $1,4 \%$, natomiast w pasywach $0,7 \%$. Zauważyć można, że najwyższą zmiennością wśród badanych zmiennych charakteryzują się inwestycje portfelowe oraz pozostałe inwestycje zagraniczne. $Z$ chwilą przystąpienia Polski do UE w 2004 r. aż do 2008 r. następował dynamiczny wzrost pozostałych inwestycji zagranicznych o ponad $104,0 \%$. Ponowny ich wzrost, po spadku w 2009 r., następował w okresie 4 lat do 2012 r., co potwierdza wcześniej przedstawione wnioski. Uzupełnieniem analizy MPI Polski jest struktura aktywów brutto.

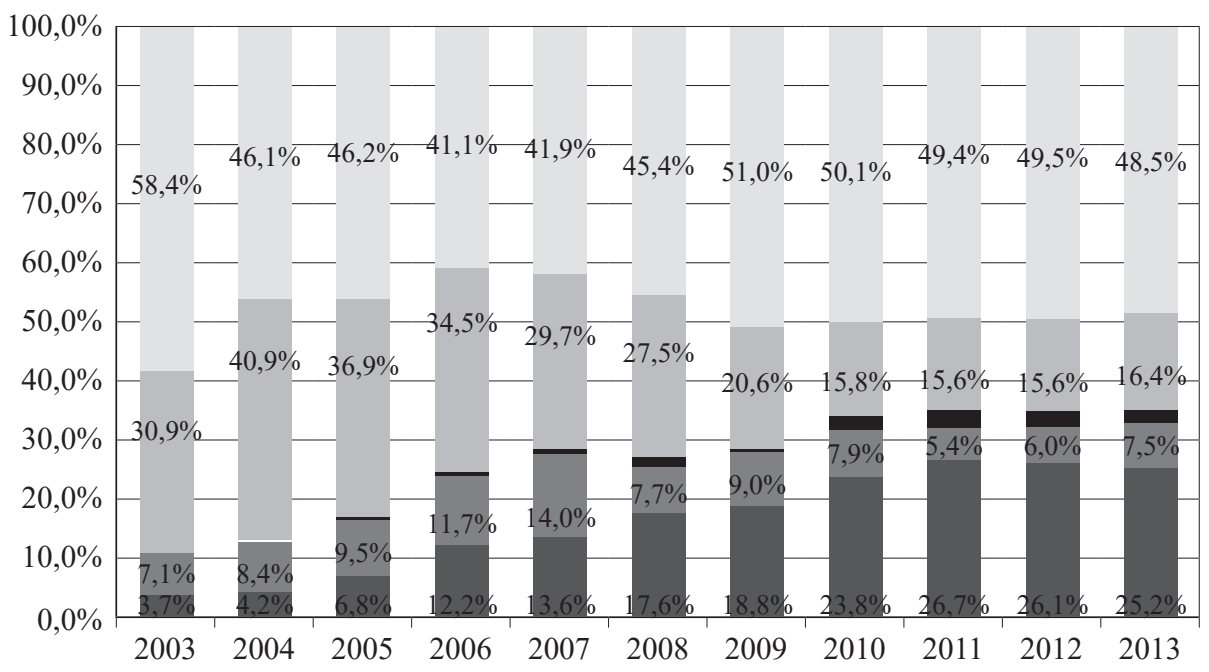

• Polskie inwestycje bezpośrednie za granicą

- Pochodne instrumenty finansowe

- Polskie inwestycje portfelowe za granicą

Oficjalne aktywa rezerwowe

Rys. 4. Struktura aktywów MPI Polski w latach 2003-2013 (w \%)

Źródło: obliczenia własne na podstawie danych NBP.

W strukturze aktywów międzynarodowej pozycji inwestycyjnej Polski najistotniejszą zmianą, jaka dokonała się $\mathrm{w}$ okresie jedenastu lat począwszy od 2003 r. do 2013 r., jest wzrost udziału polskich inwestycji bezpośrednich za granicą o ok. 20 p.p. (z poziomu 3,7\% w 2003 r. do 25,2\% aktywów w 2013 r.). Obniżył się udział pozostałych inwestycji zagranicznych o ok. połowę, tj. z 30,9\% w 2003 r. do 16,4\% w 2013 r. Dokonując przeglądu znaczenia w strukturze akty- 
wów finansowych MPI Polski, zauważyć można, że inwestycje portfelowe lokowane poza granicami naszego kraju stanowiły średniorocznie $8,6 \%$, za wyjątkiem skokowych wzrostów w latach przedkryzysowych tj. 2006-2007, wynosząc odpowiednio $11,7 \%$ i $14 \%$.

\section{GLOBALIZACJA FINANSOWA A INTEGRACJA HANDLOWA POLSKI NA TLE KRAJÓW STREFY EURO I WYBRANYCH KRAJÓW EŚW}

Obstfeld i Taylor (2002) oraz Lane i Milessi-Ferretti (2003) skonstruowali prosty miernik służący ocenie stopnia międzynarodowej integracji finansowej danego kraju $(I F I=(F A+F L) / G D P)$. Dzięki wynikom uzyskanym na podstawie dokonanych obliczeń możliwa jest wstępna ocena stopnia tej integracji. Generalnie im wyższy poziom tego wskaźnika, tym wyższy stopień międzynarodowej integracji finansowej danego kraju. Natomiast wskaźnik EQI $(E Q I=(E Q A+E Q L) / G D P)$ pozwala dokonać oceny stopnia integracji finansowej względem kapitału udziałowego danego kraju z resztą świata. Podobnie jak w poprzednim wskaźniku - im wyższy jego poziom, tym stopień integracji finansowej, mierzonej relacją kapitału udziałowego do PKB, jest wyższy. Dla Polski wyniki obliczeń przedstawiono na rys. 5.

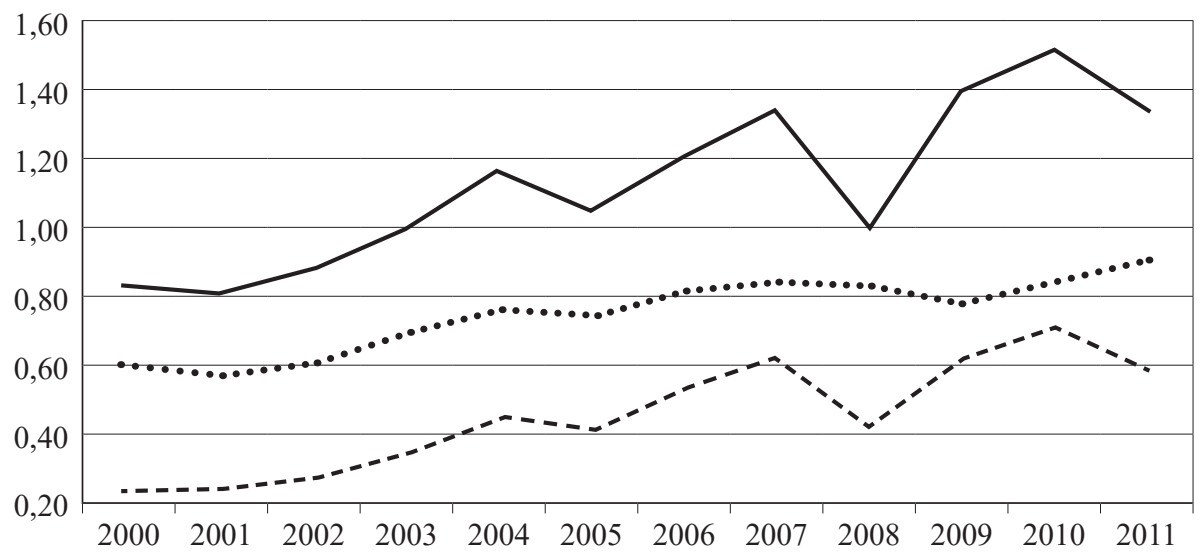

\begin{tabular}{|c|c|c|c|c|c|c|c|c|c|c|c|c|}
\hline & 2000 & 2001 & 2002 & 2003 & 2004 & 2005 & 2006 & 2007 & 2008 & 2009 & 2010 & 2011 \\
\hline IFI & 0,84 & 0,82 & 0,89 & 1,00 & 1,17 & 1.06 & 1,21 & 1,35 & 1,01 & 1,41 & 1,52 & 1,35 \\
\hline EQI & 0,24 & 0,25 & 0,28 & 0,34 & 0,45 & 0,42 & 0,54 & 0,62 & 0,43 & 0,62 & 0,72 & 0,59 \\
\hline Integracja handlowa & 0,61 & 0,58 & 0,61 & 0,69 & 0,77 & 0,75 & 0,83 & 0,84 & 0,84 & 0,79 & 0,86 & 0,91 \\
\hline
\end{tabular}

Rys. 5. Międzynarodowa integracja finansowa a integracja handlowa Polski w latach 2000-2011

Źródło: obliczenia własne na podstawie danych NBP oraz GUS. 
W okresie 2000-2011 następuje silna integracja finansowa Polski z rynkiem międzynarodowym. Dotyczy ona zarówno integracji finansowej IFI, jak i integracji względem kapitału udziałowego EQI. W $2000 \mathrm{r}$. IFI wynosi 0,84 i dynamicznie wzrasta do 2004 r. (1,17), dalej od 2005 r. do 2007 r. dynamika zmian jest wysoka i wynosi za dwa lata $25,9 \%$ z (1,06 do 1,35). Kryzys finansowy wywołał spadek stopnia międzynarodowej integracji finansowej w dwóch kategoriach - IFI oraz EQI. W 2008 r. IFI zmniejszył się do poziomu 1,01 (spadek o 25,3\% wobec roku poprzedniego), natomiast EQI obniżył się w tym samym okresie z 0,62 do 0,43, co stanowi spadek o 31\%. Największa dyspersja pomiędzy dwoma wskaźnikami występuje w 2010 r. i wynosi 0,81, natomiast najniższa w 2008 r. i wynosi 0,58.

Analiza stopnia integracji finansowej Polski w konfrontacji $\mathrm{z}$ otwartością handlową pozwala na wysunięcie wniosku, że rynki finansowe są bardziej wrażliwe na zmiany zachodzące w realnej gospodarce. Do momentu przystąpienia Polski do Unii Europejskiej w 2004 r. zarówno integracja finansowa, jak i otwartość handlowa wzrastały, osiągając odpowiednio poziomy: 1,17 i 0,77 . Ponowny etap integracji finansowej Polski przebiegał od 2005 do 2007 r. i wzrósł z poziomu 1,06 do 1,35 (wzrost o 27,5\%). W tym samym czasie otwartość handlowa Polski utrzymywała się na względnie stabilnym poziomie $(0,75 \mathrm{w} 2005$ r. i 0,83 w 2007 r.). Kryzys z 2007 r. wpłynął na osłabienie dalszej integracji finansowej Polski z rynkiem międzynarodowym. Poziom tej integracji obniżył się z 1,35 w 2008 r. do 1,01 (spadek o ponad 25\%). Ponowny etap wzrostu stopnia integracji trwał do 2010 r. i osiągnął poziom 1,52 (wzrost o 51\%) w $2010 \mathrm{r}$.

Poniżej dokonano statystycznej analizy danych i podjęto próbę oceny relacji między międzynarodową integracją finansową a otwartością finansową Polski i wybranych krajów Europy Środkowo-Wschodniej. Wśród krajów EŚW wyróżniono: Bułgarię, Chorwację, Czechy, Litwę, Polskę, Rumunię oraz Węgry. Ponadto poddano badaniu stopień integracji Polski z dwiema grupami krajów: należąc do strefy euro (EA) i do niej nie należących (nEA), będących członkami Unii Europejskiej. Kraje strefy euro obejmują 18 gospodarek. Analizą nie objęto Wielkiej Brytanii, Danii oraz Szwecji. Na rys. 6 pokazano średnią dla wyżej wymienionych krajów za okres od 2004 do 2011 r. Na osi poziomej zaznaczono poziomy średniej otwartości handlowej za lata 2004-2011, natomiast na osi pionowej-stopień średniej integracji finansowej.

Można zauważyć, że kraje ze strefy euro w porównaniu z krajami spoza niej znajdują się na przeciwległych biegunach. O ile w krajach posługujących się jednolitą walutą (EA) integracja finansowa wynosi średnio 3,23 za okres 2004-2011, to w krajach EŚW (nEA) poziom tego wskaźnika wyniósł 1,86. Wyjątek stanowią Węgry, w których poziom integracji finansowej wyniósł średnio 3,80, natomiast otwartości handlowej 1,55. Stopień integracji finansowej dla pozostałych krajów spoza strefy euro, należących do UE, kształtuje się między 1,0 i 2,0. Interesujące jest, że wartość wskaźnika otwartości dla Chorwacji wynosi 0,88, dla Polski 0,82 i Rumunii 0,76.

Analiza struktury MPI krajów należących do strefy euro oraz krajów EŚW znajdujących się poza nią dostarcza wielu interesujących wniosków. Zmiany, jakie zaszły na przestrzeni 14 lat, odnoszą się do poszczególnych komponentów pasywów MPI. 


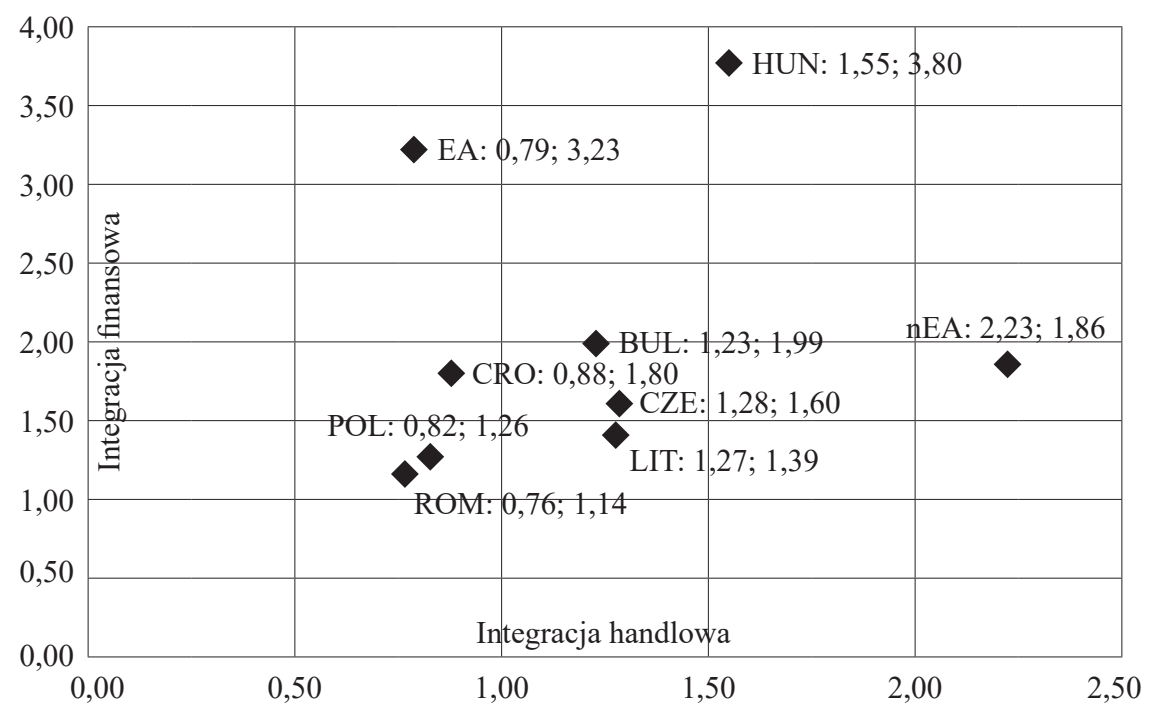

Rys. 6. Międzynarodowa integracja finansowa a integracja handlowa krajów UE Źródło: obliczenia własne na podstawie danych NBP, Eurostat i IMF.

Tabela 1

MPI netto (\% GDP) krajów strefy euro (EA) oraz krajów EŚW (nEA)

\begin{tabular}{|c|c|c|c|c|c|c|c|c|c|c|c|c|c|c|}
\hline \multirow{2}{*}{ Zmienna } & \multicolumn{10}{|c|}{ Rok } \\
\cline { 2 - 9 } & 1998 & 1999 & 2000 & 2001 & 2002 & 2003 & 2004 & 2005 & 2006 & 2007 & 2008 & 2009 & 2010 & 2011 \\
\hline \multicolumn{10}{|c|}{ NFA/GDP } \\
\hline nEA & $-0,28$ & $-0,33$ & $-0,34$ & $-0,31$ & $-0,36$ & $-0,41$ & $-0,48$ & $-0,46$ & $-0,61$ & $-0,71$ & $-0,64$ & $-0,82$ & $-0,78$ & $-0,67$ \\
\hline EA & $-0,10$ & $-0,07$ & $-0,08$ & $-0,07$ & $-0,12$ & $-0,13$ & $-0,13$ & $-0,10$ & $-0,14$ & $-0,17$ & $-0,18$ & $-0,21$ & $-0,18$ & $-0,18$ \\
\hline \multicolumn{10}{|c|}{ FDI net/GDP } \\
\hline nEA & $-0,17$ & $-0,21$ & $-0,25$ & $-0,27$ & $-0,31$ & $-0,33$ & $-0,38$ & $-0,34$ & $-0,42$ & $-0,45$ & $-0,36$ & $-0,47$ & $-0,46$ & $-0,38$ \\
\hline EA & 0,01 & 0,05 & 0,05 & 0,06 & 0,03 & 0,01 & 0,01 & 0,04 & 0,06 & 0,07 & 0,07 & 0,10 & 0,11 & 0,12 \\
\hline \multicolumn{10}{|c|}{ PI net/GDP } \\
\hline nEA & $-0,11$ & $-0,12$ & $-0,11$ & $-0,11$ & $-0,11$ & $-0,13$ & $-0,17$ & $-0,16$ & $-0,17$ & $-0,15$ & $-0,10$ & $-0,15$ & $-0,17$ & $-0,16$ \\
\hline EA & $-0,10$ & $-0,13$ & $-0,12$ & $-0,12$ & $-0,14$ & $-0,14$ & $-0,14$ & $-0,14$ & $-0,20$ & $-0,23$ & $-0,22$ & $-0,29$ & $-0,28$ & $-0,28$ \\
\hline \multicolumn{10}{|c|}{ OI net/GDP } \\
\hline nEA & $-0,14$ & $-0,14$ & $-0,14$ & $-0,09$ & $-0,13$ & $-0,17$ & $-0,15$ & $-0,13$ & $-0,16$ & $-0,21$ & $-0,24$ & $-0,33$ & $-0,31$ & $-0,28$ \\
\hline EA & 0,00 & $-0,02$ & $-0,06$ & $-0,05$ & $-0,04$ & $-0,03$ & $-0,02$ & $-0,02$ & $-0,02$ & $-0,02$ & $-0,05$ & $-0,04$ & $-0,04$ & $-0,03$ \\
\hline
\end{tabular}

Źródło: obliczenia własne na podstawie danych IMF. 
Na podstawie danych statystycznych dotyczących aktywów zagranicznych netto wybranych krajów EŚW (nEA) oraz należących do strefy euro można stwierdzić, że od 1998 r. do 2011 r. ujemne saldo MPI wobec PKB pogłębiło się ponad dwukrotnie. W $1998 \mathrm{r}$. NFA wynosiło -0,28 PKB, natomiast w $2011 \mathrm{r}$. $-0,67$ PKB, osiągając w 2009 r. maksymalną wartość -0,82 PKB. Analogicznie, w krajach strefy euro w 2009 r. wartość NFA/PKB była blisko czterokrotnie niższa i wyniosła $-0,21$ PKB. Warto podkreślić, że w krajach rozwijających się BIZ-y stanowią największy udział ujemnego salda NFA. W krajach rozwiniętych saldo BIZ/PKB wykazywało wartości dodatnie w każdym z badanych lat i kształtowało się w granicach 0,01 PKB w 1998 r. do 0,12 PKB w 2011 r. Salda kapitału portfelowego netto $\mathrm{w}$ stosunku do PKB w obu grupach krajów znajdowało się na zbliżonym poziomie od $1998 \mathrm{r}$. (nEA: $-0,11 \mathrm{PKB}$; EA: $-0,10 \mathrm{PKB})$ do 2006 r. (EA: -0,17 PKB; EA: -0,2 PKB). Od 2007 r. zauważyć można rozejście się trajektorii obu grup krajów i dyspersja salda netto PI/PKB pomiędzy krajami strefy euro (EA: -0,23 PKB) a krajami EŚW (nEA; -0,15 PKB) powiększała się z roku na rok, by osiągnąć wartości w 2011 r. odpowiednio: EA:-0,28 PKB; nEA: $-0,16$ PKB.

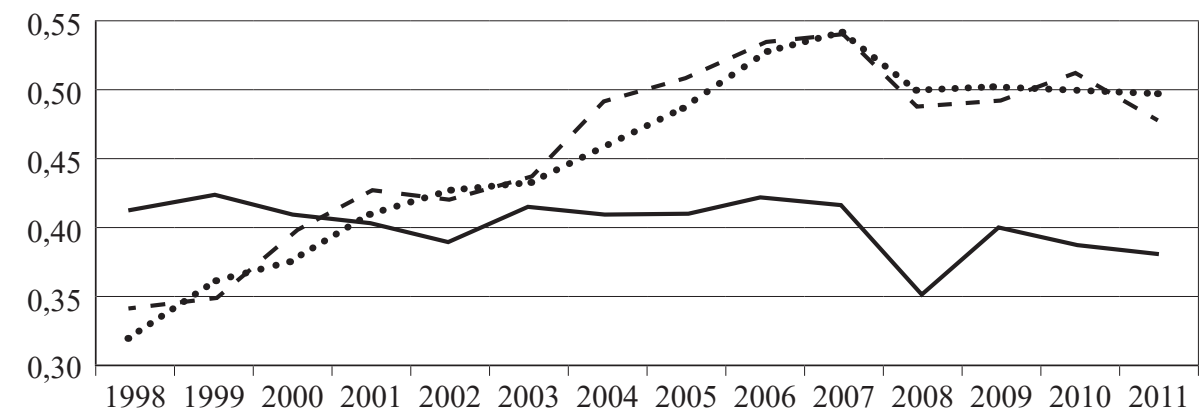

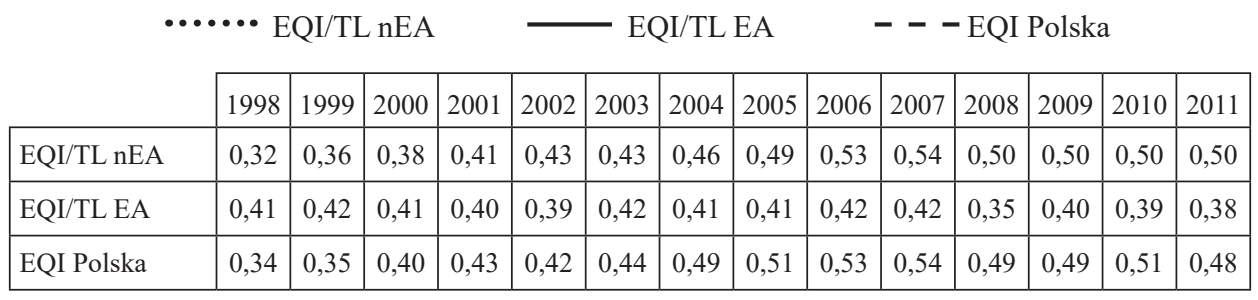

Rys. 7. Kapitał udziałowy (EQI/TL) w pasywach MPI krajów strefy euro oraz EŚW w latach 1998-2011 (w \%)

Źródło: obliczenia własne na podstawie danych NBP i IMF.

$\mathrm{Z}$ analizy danych odnoszących się do relacji sumy kapitału w formie BIZ oraz krótkoterminowego w pasywach ogółem wynika, że zmiany procentowego ich udziału w krajach posługujących się wspólną walutą są względnie jedno- 
lite, za wyjątkiem 2008 r., w którym nastąpił spadek o 7 p.p. wobec 2007 r. W wybranych krajach EŚW, na przestrzeni 10 lat od 1998 do 2007 r., wzrost tej kategorii kapitału wyniósł 20 p.p., co może świadczyć o pozytywnym postrzeganiu perspektyw polityczno-gospodarczych tej grupy krajów. Od 2004 r. różnica wobec krajów ze strefy wynosi średnio ok. 10 p.p. Na tym tle Polska nie odbiega znacząco od średniej dla krajów EŚW. W tej grupie krajów załamanie w 2008 r. wyniosło 4 p.p. Warto podkreślić, że największy udział tej pozycji finansowej w pasywach ogółem zajmują bezpośrednie inwestycje zagraniczne, średni ich udział w krajach EŚW za lata 2004-2011 wynosi 47,0\%, natomiast w krajach strefy $21,0 \%$. Dokonując analizy danych odnoszących się do udziału BIZ w strukturze kapitałowej (FDI/EQI), zauważyć można, że w okresie 20042011, w grupie wybranych krajów EŚW wskaźnik ten wynosi blisko 90\%, natomiast w gospodarkach państw ze strefy euro ok. 52\% kapitału udziałowego ogółem $(E Q I / T L)$. Obrazuje to rys. 8.

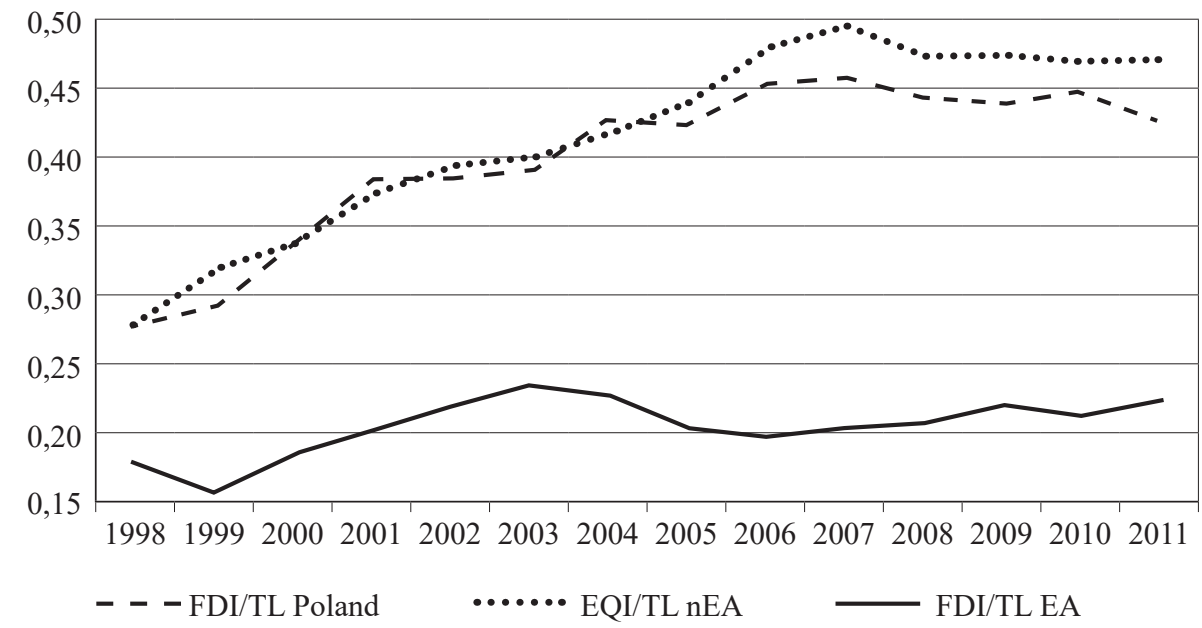

\begin{tabular}{|l|l|l|l|l|l|l|l|l|l|l|l|l|l|l|}
\cline { 2 - 13 } \multicolumn{1}{c|}{} & 1998 & 1999 & 2000 & 2001 & 2002 & 2003 & 2004 & 2005 & 2006 & 2007 & 2008 & 2009 & 2010 & 2011 \\
\hline FDI/TL Poland & 0,28 & 0,29 & 0,34 & 0,39 & 0,39 & 0,39 & 0,43 & 0,43 & 0,46 & 0,46 & 0,45 & 0,44 & 0,45 & 0,43 \\
\hline FDI/TL nEA & 0,28 & 0,32 & 0,34 & 0,38 & 0,40 & 0,40 & 0,42 & 0,44 & 0,48 & 0,50 & 0,48 & 0,48 & 0,47 & 0,47 \\
\hline FDI/TL EA & 0,18 & 0,16 & 0,19 & 0,20 & 0,22 & 0,24 & 0,23 & 0,21 & 0,20 & 0,21 & 0,21 & 0,22 & 0,21 & 0,23 \\
\hline
\end{tabular}

Rys. 8. Udział bezpośrednich inwestycji zagranicznych w kapitale udziałowym w krajach strefy euro oraz EŚW w latach 1998-2011 (w \%)

Źródło: obliczenia własne na podstawie danych NBP i IMF.

Uzupełnieniem analizy struktury pasywów MPI badanych krajów jest określenie poziomu zobowiązań $(D E B T / T L)$. Jak wynika z poniżej przedstawionych danych, średni udział kapitału dłużnego w pasywach grupy krajów z EŚW ulega 
systematycznemu obniżeniu od 68\% w 1998 r. 68\% do 46\% w 2007 r., by ustabilizować swój udział w następnych latach w granicach $49 \%$. Należy podkreślić, że w czasie kryzysu lat 2007-2010 nastąpił odwrót na rynkach finansowych od inwestycji o charakterze udziałowym w kierunku mniej ryzykownych walorów, jakimi są papiery dłużne.

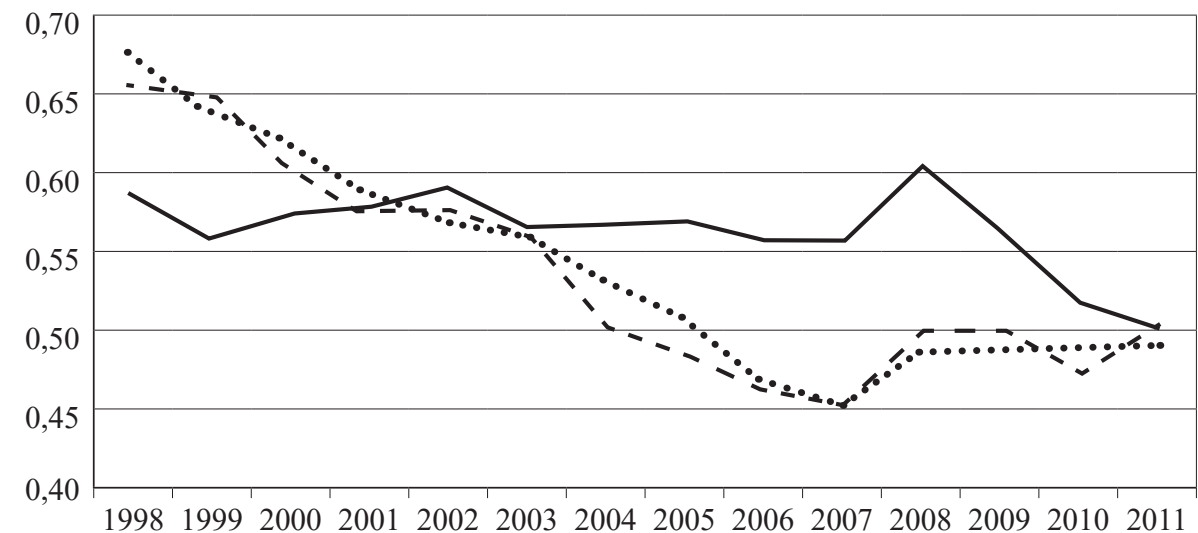

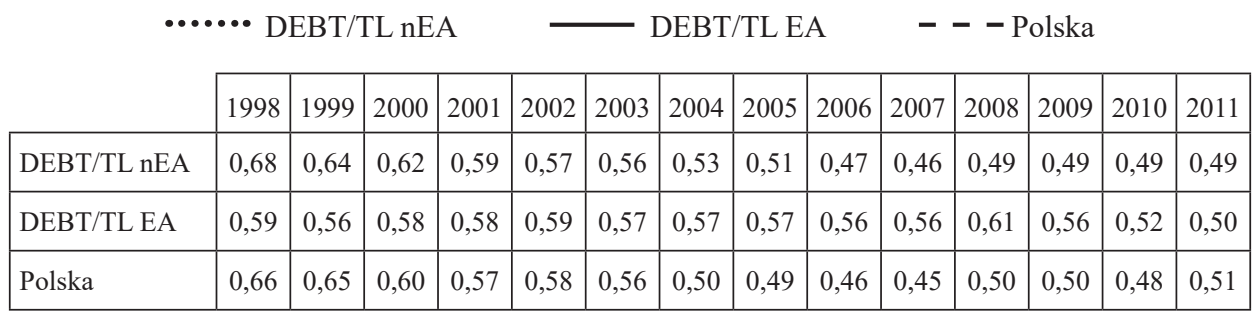

Rys. 9. Udział kapitału dłużnego w pasywach w krajach strefy euro oraz EŚW w latach 1998-2011 (w \%)

Źródło: obliczenia własne na podstawie danych NBP i IMF.

Podsumowując, w latach 1998-2011 zarówno w krajach należących do strefy euro, jak i niebędących jej członkami zachodzą istotne zmiany w strukturze MPI. Charakterystyczne jest to, że przełomowym momentem dla kształtowania się obecnej struktury MPI analizowanych krajów jest 2000 r. O ile w przypadku kapitału udziałowego widoczna była tendencja do systematycznego wzrostu jego udziału w krajach spoza strefy euro do 2011 r., to w przypadku długu było odwrotnie. Od 2008 r. wystąpił dynamiczny spadek udziału długu w strukturze pasywów z $61,0 \%$ w krajach należących do unii walutowej i zbliżył się do poziomu jego udziału w krajach spoza strefy w 2011 r., osiągając 50,0\%. 


\section{PODSUMOWANIE}

W wyniku dynamicznych przemian zachodzących w gospodarce światowej dokonują się istotne zmiany w strukturze międzynarodowej pozycji inwestycyjnej poszczególnych krajów. W wyniku przeprowadzonej analizy statystycznej można stwierdzić, że istnieją znaczące różnice w strukturze MPI pomiędzy krajami rozwiniętymi i rozwijającymi się. Ogólnie, w wyniku kryzysu w 2007 r. nastąpiła zmiana w tendencji w kształtowaniu się relacji kapitał-udziałowy dług. O ile w krajach spoza strefy nastąpił wzrost udziału długu wobec kapitału udziałowego, to w przypadku krajów z unii walutowej nastąpił jego spadek. W przypadku kapitału działowego od 2006 r. występuje dyspersja pomiędzy badanymi grupami krajów średnio ok. 10 p.p. (nEA - 53,0\%; EA - 42,0\%) do 2011 r. (nEA - 50,0\%; EA - 38,0\%). Znaczącą część kapitału udziałowego stanowią bezpośrednie inwestycje zagraniczne.

Wzrost otwartości handlowej, rozwoju finansowego, integracji finansowej i gospodarczej znajdują odzwierciedlenie w przepływach finansowych pomiędzy państwami. W okresie 2000-2011 następuje silna integracja finansowa Polski z rynkiem międzynarodowym, zarówno pod względem integracji finansowej IFI, jak i międzynarodowej integracji wobec kapitału udziałowego EQI. Generalnie następuje wzrost wartości aktywów oraz pasywów MPI. Pogłębia się ujemne saldo przepływów finansowych międzynarodowej pozycji inwestycyjnej względem PKB badanych krajów, szczególnie w krajach EŚW będących członkami UE, spoza strefy euro.

\section{BIBLIOGRAFIA}

Borensztein E., Gregorio de J., Lee J.-W. (1998), How Does Foreign Direct Investment Affect Economic Growth?, „Journal of International Economics”, 45, s. 115-135.

Catao A. V., Milesi-Ferretti G. M. (2013), External Liabilities and Crises, „IMF Working Paper”, No. $13 / 113$.

Faria A., Lane P. R., Mauro P., Milesi-Ferretti G. M. (2006), The Shifting Composition of External Liabilities, „IIIS Discussion Paper”, No. 190.

Gruić B. (2013), Determinants of international investment position, Croatian National Bank, Zagreb.

Hausmann R., Fernandez-Arias E. (2001), Is Foreign Direct Investment a Safer Form of Financing?, „Emerging Markets Review”, Vol. 2, 1, s. 34-48.

Lane P. R., Milesi-Ferretti G. M. (2000), External Capital Structure: Theory and Evidence, „IMF Working Paper", WP/00/152.

Lane P. R., Milesi-Ferretti G. M. (2001), The External Wealth of Nations: Measures of Foreign Assets and Liabilities for Industrial and Developing Countries, www.imf.org/EXTERNAL/ PUBS/CAT/longres.cfm?sk\&sk=3258 (dostęp: 20.09.2015).

Lane P. R., Milesi-Ferretti G. M. (2003), International financial integration, „IMF Staff Papers”, Vol. 50, Special Issue, s. 82-113. 
Lane P. R., Milesi-Ferretti G. M. (2006), The External Wealth of Nations Mark II: Revised and Extended Estimates of Foreign Assets and Liabilities, 1970-2004, „IMF Working Paper”, $\mathrm{WP} / 06 / 69$.

Obstfeld M., Taylor A. (2002), Globalization and Capital Markets, „NBER Working Papers”, 8846. Shin H. S. (2012), Global Banking Glut and Loan Risk Premium, „IMF Economic Review”, 60, s. $155-192$.

www.imf.org (dostęp: 20.09.2015).

www.nbp.pl (dostęp: 20.09.2015).

www.stat.gov.pl (dostęp: 20.09.2015).

\title{
Iwona Maciejczyk-Bujnowicz
}

\section{DECOMPOSITION OF POLISH INTERNATIONAL INVESTMENT POSITION WITH SELECTED COUNTRIES OF CENTRAL AND EASTERN EUROPE}

\begin{abstract}
At the turn of the twentieth and twenty-first century, worldwide significant changes were made in the structure of the external investment position. In Asia and in the countries of the Middle East, there was recorded a dynamic growth of financial surpluses, while in other developing countries there was noted a significant increase of the equity in liabilities and a strong accumulation of foreign exchange reserves. Generally, in the era of financial globalization since the $70 \mathrm{~s}$ and $80 \mathrm{~s}$ followed by a dynamic increase in the share of IIP liabilities in the GDP of developed countries. From the 90s to the beginning of the XXI century, we can note a high growth rate of the share of equity capital in the capital structure. The aim of the study is to analyze the international investment position of Poland to selected countries of Central and Eastern Europe and the countries in the euro area.
\end{abstract}

Keywords: international investment position, foreign direct investment, financial integration, the structure of the MPI. 